\title{
Modelling water yields in response to logging and Representative Climate Futures
}

\author{
Chris Taylor a, David Blair a, Heather Keith a,b,c, David Lindenmayer a,c, $*$ \\ a Fenner School of Environment \& Society, The Australian National University, Canberra, Australian Capital Territory 2601, Australia \\ b Griffith Climate Change Response Program, Griffith University, Southport, Queensland 4215, Australia \\ c National Environmental Science Program Threatened Species Recovery Hub, The Australian National University, Canberra, Australian Capital Territory 2601, Australia
}

\section{H I G H L I G H T S}

- We quantified changes in water yields due to logging and projected climate change.

- Widespread clearcut logging in water catchments reduces water yield.

- Water loss from logging may exceed impacts under some climate change projections.

- Water loss from logging may negate additional rainfall under optimistic projections.

\section{G R A P H I C A L A B S T R A C T}

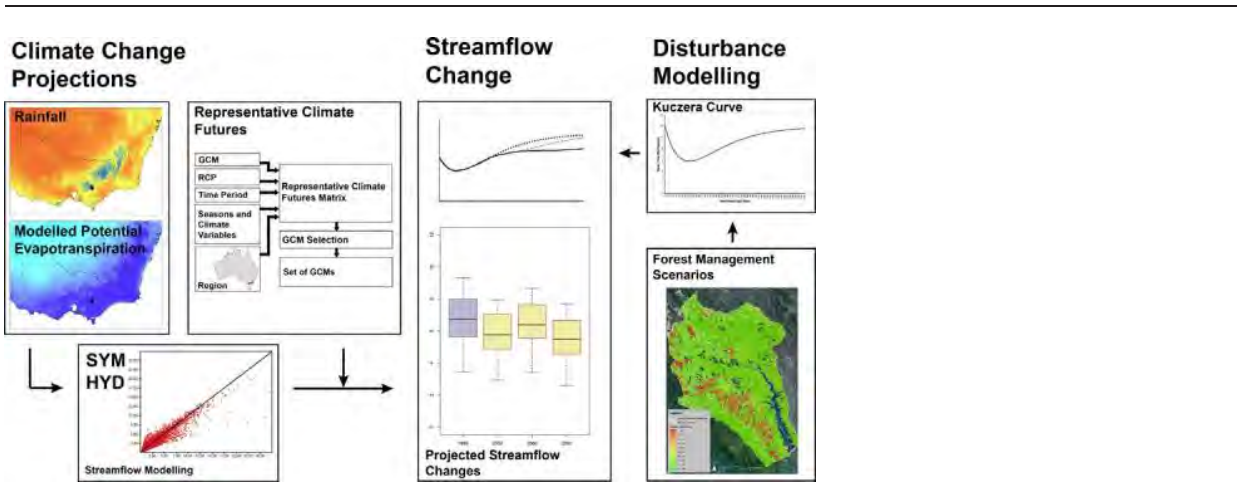

a b s tract

Natural and human disturbance along with climate change pose major challenges for resource management. This is relevant in natural forests, where conflict can occur between water provision and industrial logging. As a result, conversion of old forests to young, fast-growing stands through logging can dramatically reduce streamflow and water yield. We modelled changes in stream run-off and hence water yield from a forest catchment in response to clearcut logging and compared this with projected climate change (using a Representative Climate Futures [RCFs] approach). We focused on the Thomson Catchment, which is the largest single catchment for the city of Melbourne, south-eastern Australia. Within this catchment, we targeted our analysis at montane ash-type eucalypt forests, as these receive the most rainfall and are subject to clearcutting. We used several forest management scenarios to model changes in water yield over time. For our analysis of projected climate change, we employed a range of RCFs that represent 'consensus', 'wettest' and 'driest' scenarios to model the impacts of multiple Representative Concentration Pathways (RCPs). Our initial spatial analysis revealed that $42 \%$ of the ash-type eucalypt forests in the Thomson Catchment have been logged. Under historical and continued logging, stream runoff decreases by 40,211 ML by 2090 compared with a hypothetical baseline if logging had ceased in 1995 and 34,059 ML if logging continues beyond 2019. These losses exceed the projected impacts of climate change under the consensus and wettest scenarios, but the driest scenarios are projected to exceed these losses, consisting of 49,998 ML and 69,474 ML for RCP 4.5 and RCP 8.5, respectively. We suggest logging be excluded from the Thomson Catchment because of decreasing stream flows due to climate change and an increasing water demand due to human population growth. This study provides a quantitative ap- proach for highlighting how resource conflicts can be magnified under climate change. 



\section{Introduction}

Climate change is projected to exacerbate the risks associated with variations in the distribution and availability of water resources worldwide (WWAP, 2015). Cities and surrounding urban areas are particularly vulnerable (UNDESA, 2016). An estimated 150 million people currently live in cities with perennial water shortage, with climate change scenarios projecting a large increase in this number, possibly up to 1 billion people by 2050 (Revi et al., 2014). Competing and escalating demands for water will lead to increasingly difficult allocation decisions, creating conflict among various uses of ecosystem services (Foley et al., 2011; WWAP, 2015). Natural resource management will need to accommodate the impacts of climate change and other challenges to maintain, or genuinely achieve, more efficient, socially and ecologically sustainable production systems (Stokes and Howden, 2010; Van Vuuren et al., 2011; Whetton et al., 2012; Prober et al., 2017).

The unpredictability of Australia's weather patterns is projected to increase with climate change (CSIRO and Bureau of Meteorology, 2016). Across southern Australia, there has been a decrease in average annual rainfall since the mid-1970s with further overall declines projected from multiple climate change scenarios (Gerbing et al., 2015; Hope et al., 2015). Water supply providers are expecting that stream-flows into reservoirs supplying urban areas will decline over the long term (Howe et al., 2005). The capacity of catchments to supply water will become increasingly important, particularly in the context of competing demands from other sectors utilizing catchment areas for non-water harvesting purposes, such as logging of forested catchments for timber and pulpwood production (Hamilton, 2008; Schyns et al., 2017).

Industrial logging is permitted across a number of forested catchments supplying water to the city of Melbourne (Australia's second largest city) and surrounding urban areas (Viggers et al., 2013). These catchments are considered an important source of pulpwood for paper manufacturing and sawlog for timber production (Flint and Fagg, 2007). It has long been recognized that logging has negative impacts on water yields (Langford and O'Shaughnessy, 1980; O'Shaughnessy and Jayasuriya, 1991; Vertessy et al., 1998; Vertessy et al., 2001). These impacts result from changes in forest structure and increased levels of evapotranspiration by fast-growing young trees (Feikema et al., 2008). Following disturbance, large numbers of eucalypts germinate following disturbance (Smith et al., 2014). These trees grow rapidly, but the stocking density declines as the forest ages (Ashton, 1976). There is a strong correlation between the age of the forest and the leaf area index, which produces a marked difference in evapotranspiration and thus streamflow between young and old forests (Feikema et al., 2008). These changes in evapotranspiration and streamflow can persist for many decades (O'Shaughnessy and Jayasuriya, 1991), and may potentially compound the impacts resulting from projected climate change.

Conflict between water yield and industrial logging in Melbourne's water catchments date back well over a century (Viggers et al., 2013). Logging was excluded from some closed catchments designated in the late 19th century (Langford and O'Shaughnessy, 1980). Additional forest areas were designated as water catchments during the 1960s to increase Melbourne's water supply capacity, although logging was not excluded from all of these catchments (Viggers et al., 2013). This includes the Thomson Water Catchment, the largest in Melbourne's water supply system (Melbourne Water, 2019). The Thomson Water
Catchment produces the majority of water for the five million people living in Melbourne as well as for rural towns and some agricultural areas (Keith et al., 2017).

In the investigation reported here, we modelled changes in water yield in the Thomson Catchment in response to both the impacts of clearcutting operations and projected climate change. We explored the water yield impacts of three forest logging scenarios. (1) A hypothetical scenario where logging ceased in the Thomson Catchment by 1995. (2) A scenario where actual past logging was coupled with continued logging in the Thomson Catchment. And, (3) A scenario where logging ceases by 2019 in the Thomson Catchment. We compared these changes with a range of projected climate change impacts based on multiple Global Climate Models (GCMs).

WhileGCMs largely agree on projected temperature increases under the respective Representative Concentration Pathways (RCPs), projected changes in rainfall may vary between GCMs (Flato et al., 2013) and between regions (CSIRO and Bureau of Meteorology, 2015, 2016). To address such variability, several studies have used multimodel ensembles of GCMs presenting a range of projected impacts across catchments and watersheds (Chiew and McMahon, 2002). These include projections of wet, median and dry variants for each of low, medium and high global warming scenarios (Murphy and Timbal, 2008). This generally provides more robust information than any singleGCM(Randalletal., 2007). However, each GCM produces different climate projections, making the selection of a reduced sub-set of climate projections problematic (CSIRO and Bureau of Meteorology, 2015). Selections can be influenced by biases such as the exclusion of GCMs of lower reliability for a particular region (Ruane and McDermid, 2017). This may preclude consideration of low likelihood, but high impact, future regional climates that can be significant for adaptation planning. One way of capturing a range of projections is through the Representative Climate Futures (RCF) method (Whetton et al., 2012), which assesses each of the GCMs in terms of their respective capacity to represent projected climate change impacts across specified regions.

\section{Methods}

\subsection{Study area}

Our study area was the Thomson Catchment, which covers approximately 48,700 ha and lies $\sim 125 \mathrm{~km}$ east of the city of Melbourne (Fig. 1). The catchment provides water to the Thomson Reservoir, which was completed in 1983. The large storage capacity of the reservoir was intended to capture surplus water in wet years for subsequent use in dry years (Viggers et al., 2013). The terrain across the catchment is steep and deeply incised with elevation ranging from $400 \mathrm{~m}$ to $1565 \mathrm{~m}$ above sea level. Mean annual rainfall ranges from $1000 \mathrm{~mm}$ to $2500 \mathrm{~mm}$ across the catchment, with higher elevations receiving the highest rainfall (Peel et al., 2000).

The Thomson Reservoir is the largest reservoir of the Melbourne Water Supply system, with a capacity of 1068 billion liters or $59 \%$ of Melbourne's total water storage capacity (Melbourne Water, 2017). The Thomson Reservoir is solely reliant on streamflow from its surrounding catchment and supplies water to other reservoirs. The Thomson Reservoir receives the highest streamflow compared to other reservoirsthroughout the water supply system. The Thomson Reservoir receives around $202,930 \mathrm{ML}$ per annum or $41 \%$ of total water inflow 


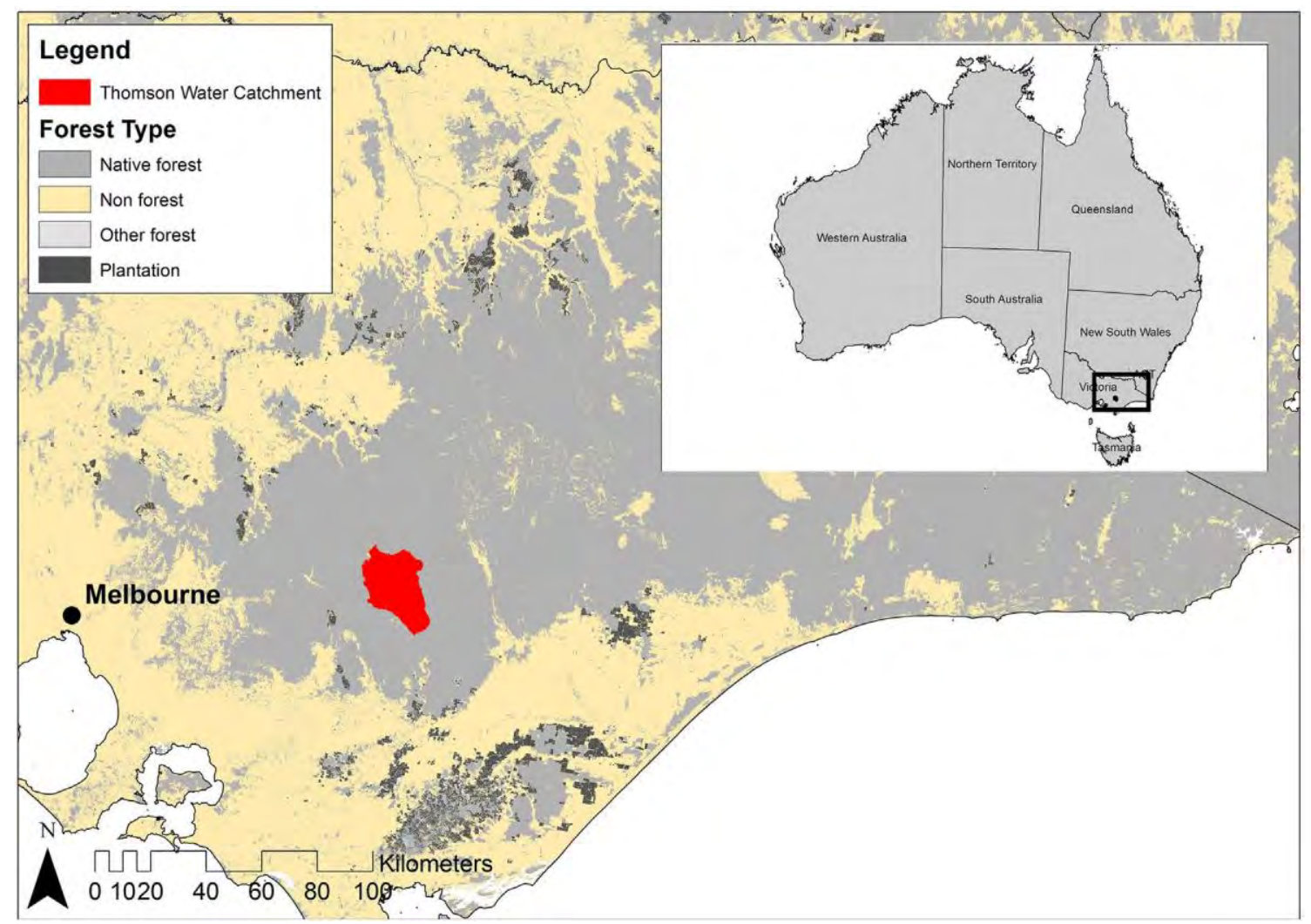

Fig. 1. Location of the Thomson Water Supply Catchment.

across Melbourne's major water catchment system (Melbourne Water, 2019).

\subsection{Land tenure}

The majority of the Thomson Catchment is state forest, covering nearly 41,000 ha or $92 \%$ of the catchment. Almost 29,000 ha or $65 \%$ of the catchment area is allocated to logging in areas classified as General ManagementandSpecial ManagementZones. Theremaining areacomprises of informal protected areas, such as Special ProtectionZones, and dedicated reserves, such as National Parks. The informal protected areas cover 12,000 ha, or $27 \%$ of the catchment. Dedicated reserves, comprising the Baw Baw National Park, cover 3517 ha or $8 \%$ of the Thomson Catchment (Table 1).

The Thomson Catchment is different to the other large catchments of Melbourne's water catchment system which, since the 1890s, have been designated as 'closed' and designated solely for the purposes of water provision (Langford and O'Shaughnessy, 1980). These closed catchments were included in the Yarra Ranges and Kinglake National Parks over a century later (Clode, 2006). The exclusion of logging from these closed catchments was to protect the water supply capacity of those catchments. However, Thomson Catchment was not afforded the same levels of protection and is subject to logging operations (Viggers et al., 2013).

The state forests of the Thomson Catchment are subject to a LegislativeSupply Agreement between the Victorian Government and a pulp and paper production company, Paper Australia Pty Ltd. (trading as Australian Paper), owned by the Nippon Paper Group (Nippon Paper Group Inc., 2009). This Legislative Supply Agreement is contained within the Forests (Wood Pulp Agreement) Act 1996 and it binds the Victorian Government to supply Paper Australia Pty Ltd. with fixed volumes of pulplogssourced from the Thomson Catchment and surrounding region for 34 years commencing in 1996 (Parliament of Victoria, 1996). The first Legislative Supply Agreement was passed in 1936 and it required the exclusion of the Thomson Catchment upon its designation as a catchment by 1967 (Parliament of Victoria, 1936). However, a revision of this Agreement in 1961 removed this requirement, thereby committing the Thomson Catchment to supply pulplogs under successive Legislative Supply Agreements (Thompson, 1961).

\subsection{Forest types}

Several forest types occur in the Thomson Catchment. Sub-alpine (Snow Gum Eucalyptus pauciflora) woodland dominates the highest elevations. Montane ash forests, including Alpine Ash (Eucalyptus

Table 1

Land tenure across the Thomson Catchment (forested areas excluding water).

\begin{tabular}{|c|c|c|c|c|}
\hline Land tenure & Description & Area (ha) & Status & $\%$ of Total \\
\hline \multirow[t]{3}{*}{ State Forest } & General Management Zone & 27,981 & Logging Permitted & $63 \%$ \\
\hline & Special Management Zone & 747 & Logging Permitted & $2 \%$ \\
\hline & Special Protection Zone & 12,153 & Logging excluded & $27 \%$ \\
\hline National Park & National Park & 3517 & Logging excluded & $8 \%$ \\
\hline
\end{tabular}


Table 2

Forest type areas across the Thomson Catchment.

\begin{tabular}{lll}
\hline Forest type & Area (ha) & $\%$ of Total \\
\hline Montane ash Forest & 18,871 & $40 \%$ \\
Mixed Species Forest & 24,973 & $53 \%$ \\
Snow Gum & 1974 & $4 \%$ \\
Non-Eucalypt & 1312 & $3 \%$ \\
Undefined & 31 & $0 \%$ \\
Total & 47,162 & $100 \%$ \\
\hline
\end{tabular}

delegatensis), Mountain Ash (Eucalyptus regnans) and Shining Gum (Eucalyptus nitens), dominate the higher elevation escarpments. Mixed species forests, including Messmate (Eucalyptus obliqua), occur throughout the remainder of the catchment. The focus of this study is the montane ash forests because they are located across the higher rainfall areas of the catchment.

Around 18,871 ha of the Thomson Catchment support montane ash forest (Table 2). Mountain Ash is the tallest of the montane ash forest types and can approach $\sim 100 \mathrm{~m}$ in height (Ashton, 1976). Depending on disturbance history, montane ash forests can be even-aged or multi-aged stands (Mackey et al., 2002). The occurrence of high severity fires produces even-aged stands. In contrast, fires of lower severity allow overstory trees to persist, while stimulating a new cohort to regenerate, resulting in multiple age cohorts (Lindenmayer and McCarthy, 1998). Alpine Ash forests occur at a higher elevation than Mountain Ash forests (Mueck, 1990), and are usually monotypic stands (Lindenmayer et al., 1996). Interspersed in smaller patches across these two forest types are Shining Gum forests (Turnbull and Pryor, 1984).

Some areas of montane ash forests across the Thomson Catchment are within nationally significant landscapes, including a site of Global Zoological Significance located around Mount Baw Baw (Mansergh and Norris, 1982). These areas provide habitat for threatened fauna. These include the Critically Endangered Victorian endemic species, the Baw Frog (Philoria frosti Spencer) (Hollis, 2004) and Leadbeater's Possum (Gymnobelideus leadbeateri McCoy) (Lindenmayer et al., 2013). They also support the Vulnerable Greater Glider (Petauroides volans Kerr) (Lindenmayer et al., 2015).

\subsection{Forest management and logging}

The main form of logging in montane ash forests is clearcutting (Lutze et al., 1999). Clearcutting within montane ash forests is typically a stand-replacing event (Lindenmayer et al., 2011). All merchantable logs are removed from a cutblock (i.e. a clearcut). A high intensity slash-fire is then applied used to burn part of the debris left behind after the logging (Flint and Fagg, 2007). This creates an ash bed, where the dominant eucalypt species are aerially seeded or replanted. As stands of eucalypt age, the stand gradually self-thin (Ashton, 1976) until the remaining trees reach their top height (Walsh and Entwisle, 1996).

Our spatial analysis of clearcutting across the Thomson Catchment was based on historical logging data from the State Forest Resource Inventory (SFRI) (DELWP, 2007), data on fire disturbance history (DELWP, 2018a), and recent logging data (DELWP, 2018b). Where SFRI data were absent across formal protected areas, such as national parks, we used Ecological Vegetation Class (EVC) information (DELWP, 2018c). The most significant disturbance in the montane ash forests across Thomson Catchment was the 1939 bushfires (DELWP, 2018a). As of 2019, the most extensive disturbance in the catchment since these bushfires has been logging. A large bushfire occurred in the catchment during January 2019. However, areas of montane ash forest remained largely unaffected (Emergency Victoria, 2019). Approximately 8190 ha of forest across the Thomson Catchment is available for logging (MBAC Consulting, 2006).

\subsection{Modelling catchment disturbance}

Using rainfall and runoff data collected from catchments supporting Mountain Ash forests across the region that were completely or partially burnt by the wildfires in 1939, Kuczera (1987) calculated a generalized relationship between the stand age and streamflow. The yield trend exhibits a long-term recovery with average yields approaching a stationary value by about age 100-150 years. The approach specifies a general equation for a post-1939 bushfire yield curve and estimates its parameters using available streamflow data:

gðtp 1/4 $L_{\max } K \delta t-1941 p e^{11-K o t-1941^{p}} ;$ if $t \geq 1941$

where $\mathrm{g}(\mathrm{t})$ is the reduction in average annual yield $(\mathrm{mm})$ following the 1939 bushfire, and $\mathrm{L}_{\max }$ and $\mathrm{K}$ are yield parameters. $\mathrm{L}_{\max }$ is the maximum yield reduction $(\mathrm{mm})$ following the fire and $t$ is the year of analysis (Kuczera, 1987). This relationship has wide error bands, indicating uncertainty around the absolute impact on water yield (Feikema et al., 2008).

The equation was modified to calculate the total stream runoff for ash montane ash forests, whereby the reduction in average annual yield was subtracted from water yield from an ecologically mature forest:

$Y^{1 / 4} M-L \max K \gamma t-2 p e^{1}-K \gamma t-2 p ;$ if $t \geq 2$

ð2p

where $Y$ is the water yield (ML/ha/year), $\mathrm{M}$ is the water yield from ecologically mature forest, $L_{\max }$ is maximum yield reduction below that of ecologically mature forest, $t$ is time in years since disturbance and $K$ is reciprocal of time taken for maximum yield depression, which was set at 0.039 (Read Sturgess and Associates, 1994). The maximum yield impact for Mountain Ash forest following disturbance for previous studies across the region is a loss of 6.15 ML/year (Kuczera, 1987; Peel et al., 2000). The Kuczera equation does not include the first two years immediately following stand mortality from fire or logging, where there is an initial increase in water yield and evapotranspiration is reduced (Feikema et al., 2008). Pre-disturbance water yield was modelled on water yields from ecologically mature Mountain Ash forest. Water loss associated with the area of younger ash trees resulting from the 1939 bushfires and previous logging up to 1995 was added to the AWRA-L v6 modelled runoff for the period 1986-2005. We spatially divided the catchment into units corresponding with age and the model was simulated for each unit.

We modelled three forest management scenarios to assess the impacts of past and current forest management and associated logging, together with alternative future management pathways. For Scenario (1), we modelled the water yield where logging ceased in 1995. We used this to quantify the water yield impacts of logging up to 1995, which aligns with the baseline year used in our projected climate change impact modelling. For Scenario (2), we modelled water yield resulting from historical forest management and associated logging, together with a future projection of continued logging, based on previous annual logging rates for the period between 1997 and 2017. For Scenario (3), we modelled the water yield loss resulting from historical forest management and associated logging, but logging was to cease by 2019 . These projections were modelled assuming no climate change.

\subsection{Climate change and the Representative Climate Futures}

A set of Representative Climate Futures (RCFs) can be used across a given region to describe plausible future climates (Whetton et al., 2012). Based on selected climate variables, the RCF consists of a multipurpose decision-support tool to assist in the application of climate change projections for impact assessment and adaptation planning (Clarke et al., 2011; Whetton et al., 2012). The RCFs were derived from a web-based tool, www.climatechangeinaustralia.gov.au, hosted 


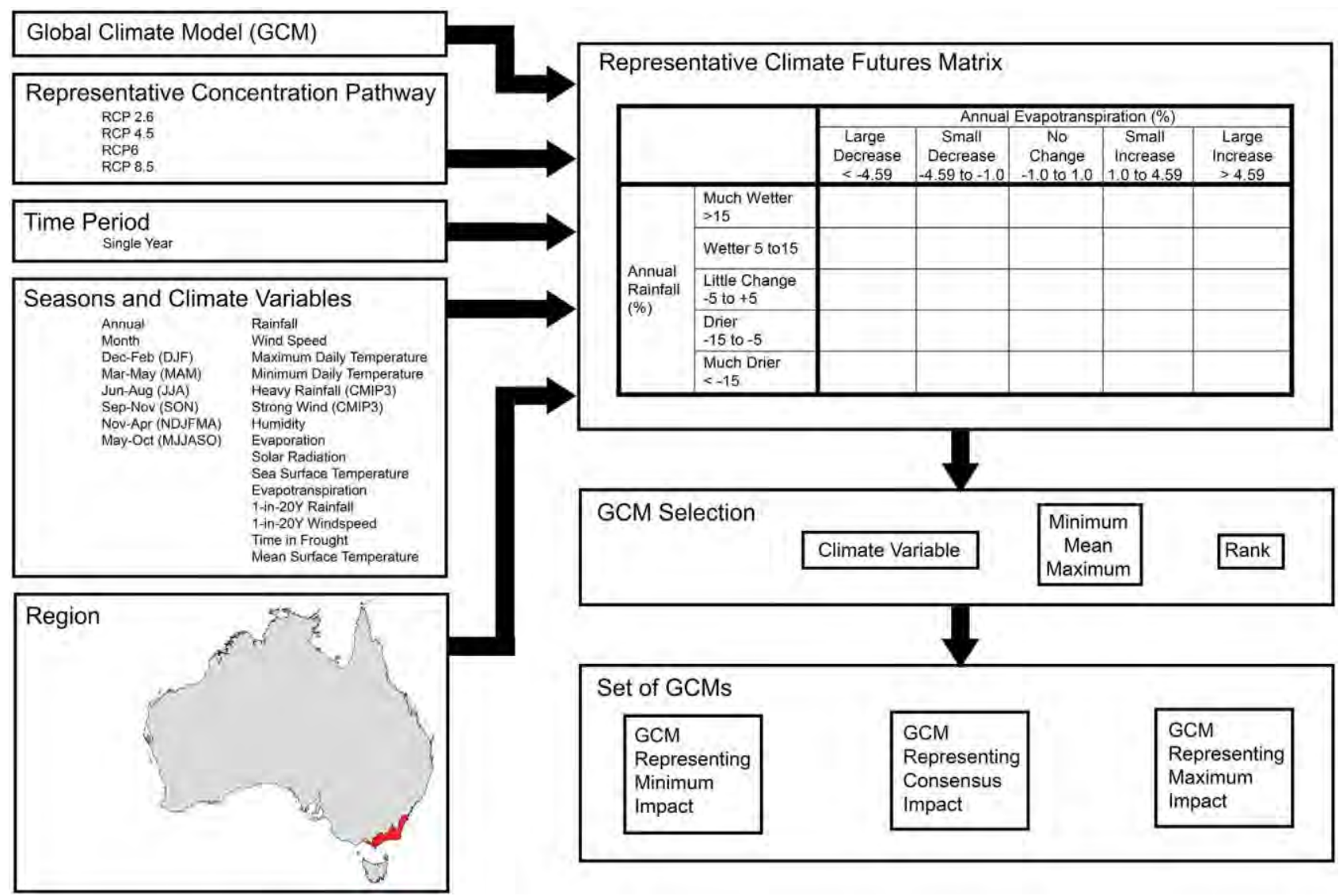

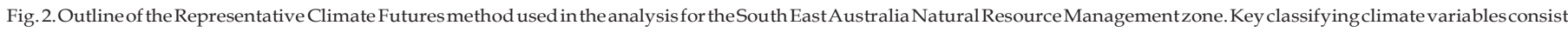
of rainfall and temperature, RCPs and the projection year (after Taylor et al., 2018).

by the CSIROClimate Change in Australia project. A four-step process was used in this study, the first step involved generating the RCFs; the second examined and applied the model results; the third identified a representative GCM for each key climate future; and the final step applied the results in an impact assessment (Fig. 2).

Our study focused on rainfall and potential evapotranspiration variables. We selected the Natural Resource Management (NRM) Sub-Zone of South Eastern Australia for analysis, which included the Thomson Catchment. We used the full suite of available GCMs and organized individual GCMs into a 'consensus' case, a 'wettest' case, and a 'driest' case. The 'consensus' case consisted of at least $30 \%$ or more of a total number of models that were aligned around changes in relation to the baseline climate, consisting of the period 1986-2005 centred on 1995. We defined the 'wettest' case as the climate future resulting in the highest rainfall and least potential evapotranspiration. We defined the 'driest' case as the climate future resulting in the least rainfall and highest potential evapotranspiration (Whetton et al., 2012). Each GCM was ranked against a multivariate ordering technique according to the mean, minimum and maximum values (Kokic et al., 2002). For example, the GCM closest to the multi-model mean was selected for the 'consensus' case. The RCF outputs were the smoothed average of the GCM grid cells across the NRM sub-zone. These consisted of monthly percentage changes for rainfall and potential evapotranspiration. We applied the delta change factors across local climate information for the NRM subzone (Taylor et al., 2018). We used the year 2090 for the analysis because the RCF tool extends to this year and the climate signal would be strongest (Taylor et al., 2018). The GCM selected for the year 2090 was used for all other years. Each modelled year was projected in 20year periods and this represented the change relative to the base year of 1995 used in the GCMs, averaged ten years either side (1986-2005) (CSIRO and Bureau of Meteorology, 2015).
The Representative Concentration Pathways (RCPs) used in this study were sourced from the pathways described by Van Vuuren et al. (2011), being RCP 4.5 and RCP 8.5. We selected them to represent the highest impact and mid-impact pathways. RCP 4.5 was the most optimistic pathway where potential evapotranspiration was modelled under the RCFs and radiative forcing was projected to increase (extra energy held in the lower atmosphere due to greenhouse gasses) by $4.5 \mathrm{~W} / \mathrm{m}^{2}$ in 2100 , compared to pre-industrial levels. Greenhouse gas stabilisation would be achieved with global greenhouse gas emissions peaking by 2040 and then declining. RCP 8.5 projected the highest emission scenario with an additional radiative forcing of $8.5 \mathrm{~W} / \mathrm{m}^{2}$ by 2100 compared with pre-industrial levels, with greenhouse gas emissions continuing to rise (Riahi et al., 2011).

\subsection{Rainfall/runoff modelling under Representative Climate Futures}

We used the lumped conceptual daily rainfall-runoff model, SIMHYD (Chiew and McMahon, 2002), to estimate daily runoff across the montane ash forests in the Thomson Catchment. It has been used to model projected climate change impacts on stream runoff across catchments throughout Australia (Chiew et al., 2009). SIMHYD simulated rainfall by filling an inception store, which was emptied each day by evaporation. The excess rainfall was subjected to an infiltration function determining infiltration capacity, with excess rainfall becoming runoff. It modelled runoff from infiltration excess runoff, interflow, saturation excess runoff and base flow (Chiew et al., 2002). The model was accessed through the Rainfall Runoff Library (RRL) (Perraud et al., 2003). SIMHYD required baseline input parameters of daily rainfall, potential evapotranspiration and runoff for model calibration.

To run SIMHYD, we used historical daily rainfall and potential evapotranspiration (PET) data from 1986 to 2005 centered on the 
1995 base year, along with Daily Runoff data,. We sourced climate data from the Australian Landscape Water Balance model (AWRA-L v6) (Frost et al., 2018). The AWRA-L v6 ran on a daily timestep and $0.05^{\circ}$ grid (approximately $5 \mathrm{~km}$ ) simulating the landscape water balance for Australia from 1911 to 2019. Key outputs from the AWRA-L model included surface runoff, soil moisture, evapotranspiration, and deep drainage. The PET data were calculated according to the Penman (1948) equation as a combination of net radiation (the energy required to sustain evaporation) and vapor pressure deficit (multiplied by a wind function) (Frost et al., 2018). Rainfall data were interpolated from multiple station records and provided on a $0.05^{\circ}$ grid across Australia. Streamflow was sourced from surface runoff, baseflow and interflow (Frost et al., 2018).

The SIMHYD model was calibrated against modelled daily streamflow data between 1986 and 2005 from AWRA-L v6. In the model calibration, parameters in SIMHYD were optimized to maximize the Nash-Sutcliffe efficiency of daily runoff (Chiew et al., 2009). We modelled RCF projections by scaling calibrated monthly rainfall and PET data in accordance with the change factor under the respective GCM for the specific projection 20 year periods centered on 2030, 2060 and 2090. Future forest management scenarios were not included in this part of the analysis.

\subsection{Comparison of impacts between forest management and projected cli- mate change}

The modelled impacts of forest management scenarios were compared with the modelled impacts of projected climate change under the RCFs using 1986-2005 period centred on 1995 as the baseline period. This was the baseline period used in the RCF approach (CSIRO and Bureau of Meteorology, 2015). The baseline runoff we obtained through AWRA-L v6 was partly modelled on the condition and growth stage of the vegetation at that particular time (Frost et al., 2018). Modelling our forest management scenarios with 1995 as the baseline year allowed for consistency in our comparative analysis of projected impacts. We calculated and analysed the impacts of forest management scenarios with the median impacts projected under the RCFs.

\section{Results}

\subsection{Disturbance across the catchment}

Inclusive of all forest types, approximately 8250 ha or $17 \%$ of the Thomson Catchment has been logged since the 1939 bushfires. Of this logged area, around $81 \%$ is concentrated within the montane ash forests (Fig. 3). Clearcut areas in montane ash forests consist of 7790 ha or $42 \%$ of the montane ash forest area across the catchment. Approximately 4619 ha of montane ash forest is now younger than 40 years. Around 3800 ha of forest is allocated for logging under a Timber Release Plan, issued by VicForests (2019). Approximately 3000 ha or $80 \%$ of the gross area proposed for logging in the next five years is montane ash forest.

\subsection{Water yield loss resulting from disturbance}

The modelled median water yield from montane ash forests for the 1995 baseline period of 1986-2005 was 125,358 ML/yr for the total montane ash forest area of 18,871 ha. The average age of unlogged montane ash forest for the period 1986-2005 was 56 years, largely as a result of the 1939 bushfires. We modelled an average runoff yield of $6.72 \mathrm{ML} /$ ha/yr from these forest areas, with 4.28 ML/ha/yr of loss in runoff as a result of the average age of the forest at that time. We calculated that old growth montane ash forest would yield 11.0 ML/ha/yr of runoff across this area. Compared with Scenario (1), where logging would have ceased in 1995, we calculated that continued logging would decrease runoff by 14,166 ML, 33,679 and 40,211ML for 2030, 2060 and 2090 , respectively, assuming no projected climate change impacts
(Fig. 4). If logging were to cease by 2019, we projected gains in water yield to be 2606 ML, 21,974 and 34,059 ML by 2030, 2060 and 2090, respectively.

\subsection{Projected climate change scenarios}

Our RCF analysis resulted in three GCMs selected each for RCP 4.5 and RCP 8.5 (Table 3). All GCMs projected increases in potential evapotranspiration for the Year 2090 but they varied in their respective rainfall outputs. Under RCP 4.5 for 2090, the Consensus GCM IPSL-CM5B-LR projected a $10 \%$ decline in rainfall and $7 \%$ increase in potential evapotranspiration. Under RCP 8.5 for 2090, the Consensus GCM CCSM4 projected a $1 \%$ decline in rainfall and $18 \%$ increase in potential evapotranspiration. Under RCP 4.5, the wettest GCM GISS-E2-R-CC projected a $6 \%$ increase in potential evapotranspiration and a decline of $1 \%$ in rainfall by 2090. The wettest GCM, FGOALS-s2, under RCP 8.5 projected a larger increase in rainfall of $21 \%$ and an increase in potential evapotranspiration of $24 \%$. The driest GCMs under RCP 4.5 and 8.5 projected declines in rainfall of $22 \%$ and $26 \%$, respectively, with increases of $12 \%$ and $20 \%$ for potential evapotranspiration, respectively.

\subsection{Modelled water yields under Representative Climate Futures}

Our modelling using SIMHYD resulted in a total of 181 model runs and 181 objective function evaluations. We optimized the model to a Rosenbrock method, resulting in a Nash-Sutcliffe Criterion for Calibration score of 0.901 . Our analysis revealed a median water yield of 6.72 $\mathrm{ML} / \mathrm{ha} / \mathrm{yr}$ for the period 1986-2005. The median runoff under modelled AWRA-L v6 input data was $6.55 \mathrm{ML} / \mathrm{ha} / \mathrm{yr}$. We projected the modelled median water yield from the total area montane ash forests for the 1995 baseline period of 1986-2005 to be 126,787 ML/yr.

The SIMHYD runoff under RCP 4.5 and RCP 8.5 was projected to decline under the Consensus and Driest RCFs, with the wettest RCF showing little change under RCP 4,5 and an increase under RCP 8.5 (Fig. 5). For 2090, the median declines projected by the consensus GCMs under RCP 4.5 and 8.5 were 25,301 ML and 23,077 ML, respectively. The median declines were greatest under projections by the Driest GCMs, with water yield reductions of 49,998 ML and 69,474 ML, respectively. Under RCP 4.5, we projected only a limited change in water runoff for the wettest GCM for 2090, with a small decrease of 478 ML. However, the wettest GCM under RCP 8.5 projected an increase in median runoff of $18,798 \mathrm{ML} / \mathrm{yr}$. The greatest increase to water runoff was projected under RCP 8.5 for the wettest case, with an increase of 28,157 ML in 2060.

\subsection{Comparison of disturbance impacts with projected climate change}

The impacts of logging exceeded those of projected climate change by 2090 under the wettest and consensus RCFs. The impacts of logging exceed the projected climate change impacts of the 'consensus' RCF by 14,910 ML and 17,133 ML by 2090 for RCP 4.5 and RCP 8.5 , respectively. For the 'wettest' RCF under RCP 4.5, logging exceeded the projected climate change impact by 39,733 ML. For the 'wettest' RCF under RCP 8.5, the projected increase in runoff was less than the loss incurred by logging by 21,413 ML. Under this RCF, the increases to runoff could mitigate reductions incurred by logging. The 'driest' $R C F$ s exceeded the impacts of logging, with further losses of $9787 \mathrm{ML}$ and 29,263 ML for RCP 4.5 and RCP 8.5, respectively.

\section{Discussion}

There is considerable potential for conflicts associated with the use of natural resources such as timber and water (Luo et al., 2018). We conducted a spatial and temporal analysis of the effects of logging on water provision in a forested catchment and compared these with the impacts of future climate change projections. Our analyses focused on a critical 


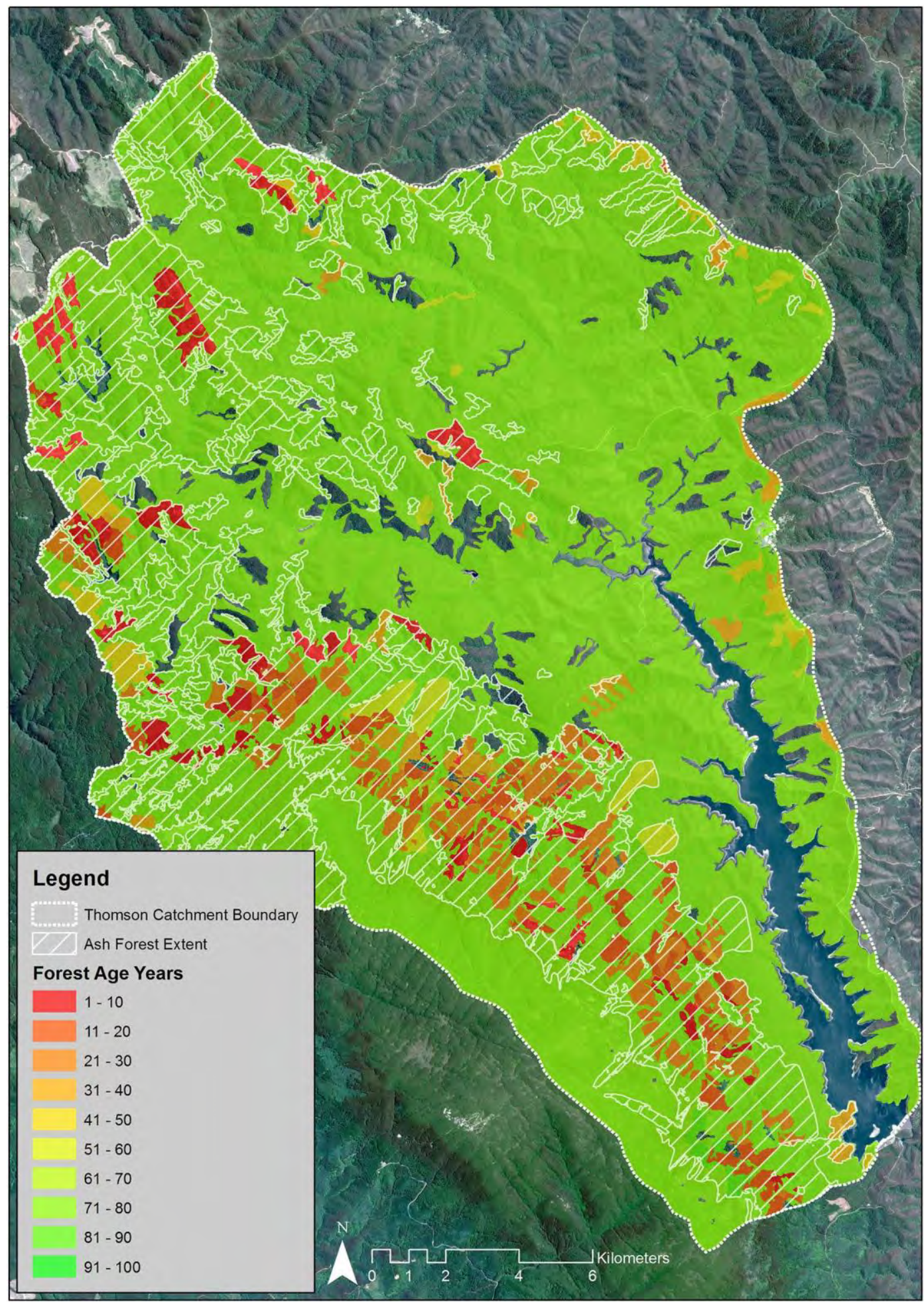

Fig. 3. Forest age class distribution across the Thomson Catchment (DELWP, 2007).

part of the water supply for the city of Melbourne, the second largest city in Australia. We targeted montane ash forests in our study because they receive some of the highest rainfall and they are where the majority of logging occurs. Ouranalysesindicated that logginginmontaneash forests may have a greater impact on annual water yield compared with the impacts of a number of climate futures. Given the Thomson Catchment contributes over $40 \%$ of total stream runoff across the water supply system for Melbourne, this has significant ramifications for both water security and wood supply. Thus, our investigation is an example of resource prioritization. That is, competition for land and forest for wood products versus water provision. In the remainder of this paper we discuss the key implications of our findings then conclude with policy recommendations for forest and watermanagement.

\subsection{Relationships between logging and wateryield}

A series of studies in the montane ash forests of Victoria have demonstrated how logging can influence water yields in water catchments 


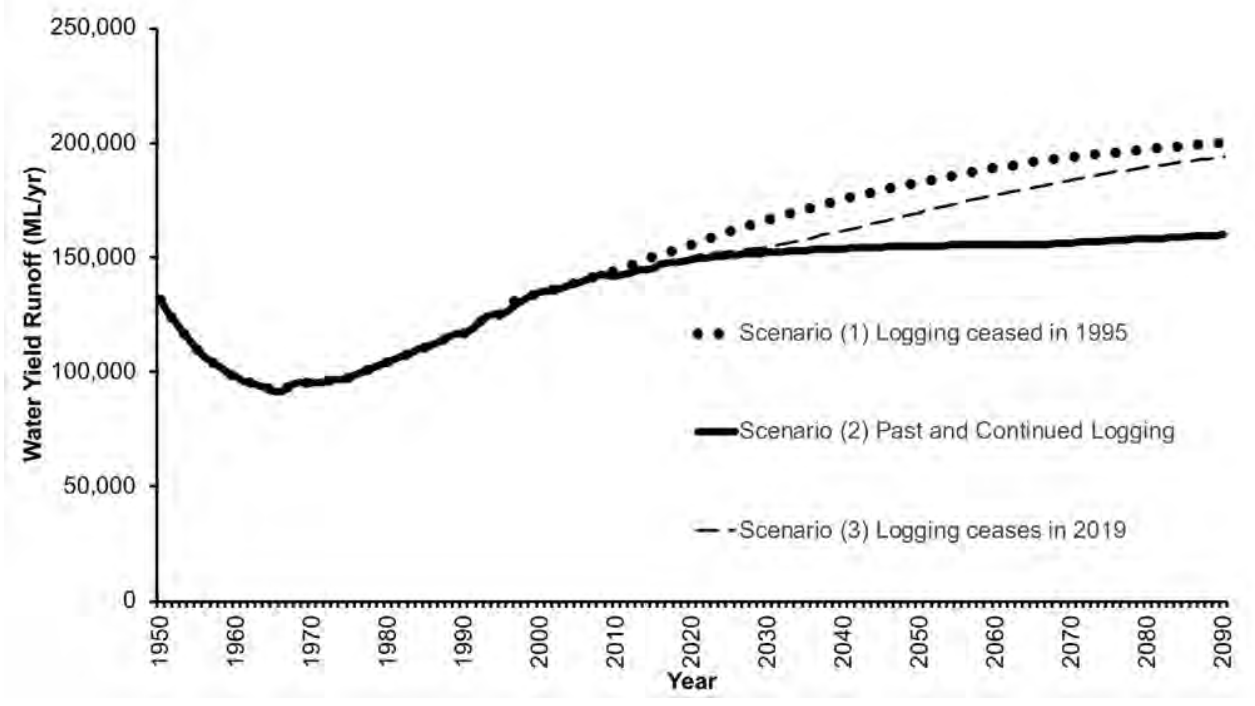

Fig. 4. Water yield runoff for Scenarios (1) Logging ceased in 1995, (2) historic and future logging, (3) Cessation of logging by 2019, based in the equation developed by Kuczera (1987).

(O'Shaughnessy and Jayasuriya, 1991; Vertessy et al., 2001) (reviewed by Viggers et al., 2013). Logging disturbance removes mature stands of trees which are replaced by fast-growing young trees. Such changes in forest structure and tree replacement lead to increased levels of evapotranspiration in regenerating stands (Feikema et al., 2008). This is because there are strong relationships between the age of the forest and the leaf area index, leading to large differences in evapotranspiration and thus streamflow between young and old forests (Feikema et al., 2008).

Our analyses indicated that logging operations occurring after 1995 in montane ash forests across the Thomson Catchment could result in an annual loss of over 14,000 ML in water yield by 2030 . Continued logging as per current management plans, would lead to greater annual losses of $\sim 34,000 \mathrm{ML}$ and $\sim 40,000 \mathrm{ML}$ by 2060 and 2090 , respectively. Based on an average consumption of 1611 of water per person per day (Melbourne Water, 2018), this loss equates to the annual consumption of water for nearly 600,000 people by 2060 alone, or more than the total current human population of the Australian State of Tasmania. This projected decline is set within the context of recent declines in streamflow across the Thomson Catchment (Melbourne Water, 2017) and an increasing population for Melbourne, which has grown by 557,000 people in the 5 years to 2017, recently passing 5 million people (ABS, 2018). A report by Melbourne Water (which is the agency responsible for Melbourne's water supply) has highlighted major concerns about water security for the city by 2030 (Chalkley-Rhoden, 2017).

Past governments in Victoria have generally prioritized the provision of water over wood production with several major water catchments closed to logging and other forms of anthropogenic disturbance (Viggers et al., 2013). The first Legislative Supply Agreement to supply pulplogs from Victorian state forests to the then Australian Paper Manufacturers (APM) facility at Maryvale, featured a clause where the Thomson Catchment was to cease being part of the Agreement by 1967 (Parliament of Victoria, 1936). This clause was removed in the 1961 Amendment of the Agreement and logging continues, with $87 \%$ of logging taking place after 1967 across all forest types. Moreover, the current Timber Release Plan has assigned a further 3800 ha for logging across the Thomson Catchment (VicForests, 2019). Our work quantifies the extent of loss of water yield associated with past logging operations and the likely future losses as a result of ongoing logging.

\subsection{Impacts of climate change}

The Representative Climate Futures' projection presents a range of possible future climate change projections, all of which require consideration in planning for adaptation. The critical advantage of this approach is that it provides simplified projections, while also addressing

Table

3 Representative ClimateFutures for annual rainfall change projected under RCP 4.5 and RCP8.5forSouth East Australia. Case descriptions are listed against their respective Global Climate Models (GCMs) and the classification for modelled years 2090

\begin{tabular}{|c|c|c|c|c|}
\hline $\mathrm{RCP}$ & $\mathrm{RCF}$ & Annual rainfall \% & Annual evapotranspiration \% & GCM \\
\hline \multirow[t]{3}{*}{4.5} & Wettest & Little Change -5 to +5 & $\begin{array}{l}\text { Small Increase } \\
1.0 \text { to } 4.59\end{array}$ & GISS-E2-R-CC \\
\hline & Consensus & Drier -15 to -5 & $\begin{array}{l}\text { Large Increase } \\
\text { N } 4.59\end{array}$ & IPSL-CM5B-LR \\
\hline & Driest & Much Drier b -15 & $\begin{array}{l}\text { Large Increase } \\
\mathrm{N} 4.59\end{array}$ & GFDL-CM3 \\
\hline \multirow[t]{3}{*}{8.5} & Wettest & Much Wetter N15 & $\begin{array}{l}\text { Large Increase } \\
\mathrm{N} 4.59\end{array}$ & FGOALS-s2 \\
\hline & Consensus & Little Change -5 to +5 & $\begin{array}{l}\text { Large Increase } \\
\mathrm{N} 4.59\end{array}$ & CCSM4 \\
\hline & Driest & Much Drier $b-15$ & $\begin{array}{l}\text { Large Increase } \\
\mathrm{N} 4.59\end{array}$ & GFDL-ESM2M \\
\hline
\end{tabular}



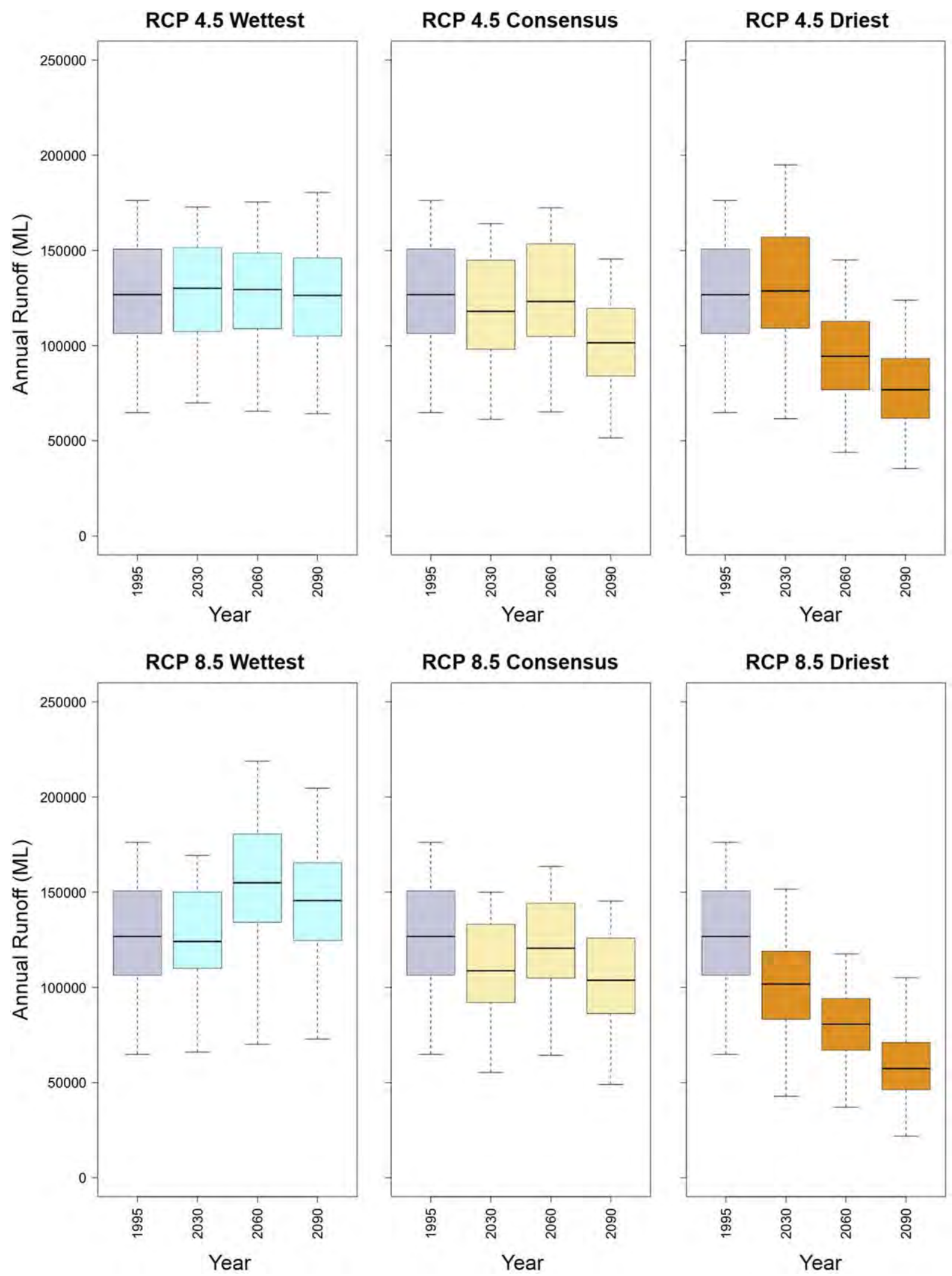

Fig. 5. Water yield runoff under the Wettest, Consensus and Driest GCMs for RCP 4.5 and RCP 8.5 .

uncertainty. There are N40 GCMs used in the Coupled Model Intercomparison Project Phase 5 (CMIP5) (CSIRO and Bureau of Meteorology, 2015), where each GCM contains its own conditions (Flato et al.,
2013). The RCF approach facilitates a selection of a sub-set of GCMs that uses internally consistent data from each GCM and the variables relevant for catchment modelling (Clarke et al., 2011; Whetton etal., 
2012). This approach provides a range of climate change projections and their associated impacts on water runoff, while incorporating the internal variables of each of the GCMs.

Our results suggest that water runoff will decline under the 'consensus' and 'driest' representative climate futures. Under a future 'no logging' scenario, the resulting increasing age of the forest may negate some of this impact with increased runoff being returned to the catchment. The scenarios of continued logging risk exacerbating the overall reductions associated with projected climate change, particularly under the 'consensus' and 'driest'RCFs. Further modelling of future logging scenarios under RCFs would provideinsight to these compounded impacts.

We have presented a range of representative climate futures but the current trend for runoff across Melbourne's water supply catchments is in decline. The 2017-2018 inflows of 413,000 ML to Melbourne's four major reservoirs, including the Thomson Reservoir, were 33\% below the long-term annual average for the period (1913-14 to 1996-97) and $16 \%$ below the average for the last 30 years (Melbourne Water, 2018). The influence of this decline is uncertain; whether it is a direct signal from current climate change, a reduction of forest age due to logging and recent fires (Feikema et al., 2013), or a combination of these drivers. Rainfall declines have been observed throughout the region and more broadly throughout south-eastern Australia. Moreover, there has been clear downward trend in rainfall since the 1990s in southern parts of eastern Australia, and especially in Victoria (Melbourne Water, 2016; Bureau of Meteorology, 2018).

\subsection{Previous studies modelling water yield changes in ash forests}

Many studies have shown that disturbance in montane ash forests decreases water yield (Langford and O'Shaughnessy, 1980; Kuczera, 1987; Read Sturgess and Associates, 1994; Vertessy et al., 1998; Watson et al., 1998; Peel et al., 2000; Vertessy et al., 2001; Mein, 2008). The majority of these studies were based on disturbance experiments established during the 1950s and 1960s in the Maroondah Catchment (Watson et al., 1998). Ronan and Duncan (1980) projected an average water yield reduction of $81 \mathrm{~mm}$ or

$0.81 \mathrm{ML} /$ ha by 2075, if logging was to have commenced in 1985 across the Maroondah Catchment and a 60 year cutting rotation was then maintained. Later, Read Sturgess and Associates (1994) modelled a number of alternative forest management scenarios across the Thomson Catchment and compared these with current management. If logging had ceased in 1992, around 15,000 ML of water yield would have been returned to the catchment by 2050 (Read Sturgess and Associates, 1994). These studies used either the equation by Kuczera (1987) or other models where water yield was similarly correlated with the age of the forest (Langford and O'Shaughnessy, 1980; Read Sturgess and Associates, 1994).

Reductions in water yield across the Thomson Catchment as a result of disturbance also were examined using the Macaque model (Peel et al., 2000). This model simulates changes in catchment water yield through changes in Leaf Area Index (LAI) and stomatal conductance (Jaskierniak, 2011). The Macaque model estimates that water yield will be most affected by disturbance in montane ash forests (Peel et al., 2000). In a more recent study, the Macaque model was used to model bushfire disturbance across the Thomson Catchment, where a reduction of up to a $22 \%$ in water yield was projected under a scenario of frequent bushfires (Feikema et al., 2008; Lane et al., 2010). In a further study, Mein (2008) used the Macaque model and projected water yield losses resulting from logging across the Thomson Catchment, in addition to multiple smaller water catchments where logging is also permitted. If logging were to have ceased in 2009/10, up to 16,000 ML/yr in water yield would have been returned across all water catchments by 2050 (Mein, 2008).

\subsection{Caveats}

The Kuczera equation is considered to be a useful representation of the potential impacts of forest disturbance on water yield (Jaskierniak, 2011). However, there are challenges in extrapolating the Kuczera equation across a broad range of environmental conditions (Jaskierniak, 2011). The Macaque model can provide more detailed analysis than the Kuczera equation through its representation of physical processes occurring within a water catchment (Peel et al., 2000). However, it is challenging to apply the Macaque model because it contains over 70 parameters and most are default values (Jaskierniak, 2011). Many of these parameters require calibration, but data for them can be difficult to obtain for remote catchments (Jaskierniak et al., 2016), as well as obtaining all of the GCM variables for the respective climate inputs.

A simpler approach has been developed by Jaskierniak et al. (2016) and Benyon et al. (2015), which uses measures of sapwood area derived from basal area and tree stocking density estimates. These inputs provide greater certainty in modelling with strong correlations between predicted and observed streamflow. However, these parameters are reliant on extensive LiDAR mapping to obtain accurate estimates of tree basalareaand stocking density. Theacquisition of such data was beyond the scope of this study.

The impacts of future fire were omitted from this study because the location, extent and severity of future fire are difficult to predict. Future high severity fire would have similar effects on water yield to clearcut logging. Additional fires would add to the effects of logging on water yield. Furthermore, several studies have shown that logged and regenerated montane ash forests are significantly more likely to burn at high severity than intact (undisturbed) stands (Taylor et al., 2014; Zylstra, 2018). These high severity fires are typically stand-replacing events in montane ash forest (Ashton, 1976) and correspond with a reduction in the age of the forest after the fire, leading to a reduction in water yield (Vertessy et al., 2001; Lane et al., 2010). Future fire severity modelling under representative climate futures was beyond the scope of this study.

Development of specific forest growth modelling under projected climate change would provide further insights for future logging and associated forest management. Such modelling could be designed around the GCM variables as well as additional variables, such as the impact of increased carbon dioxide fertilisation on plant growth (O'Leary et al., 2015). A number of models used in agriculture and cropping simulations account for these variables and provide valuable insight as to the impacts of projected climate change on animal and plant productivity (Keating et al., 2003; Meyer et al., 2018; Taylor et al., 2018). These models would allow for the simulation of interactions between projected climate change impacts and future forest management scenarios along with their respective impacts on water runoff.

\subsection{Policy implications}

Our study has focused on the extent of past and likely future reductions in water yield resulting from future forest management scenarios and representative climate futures across the Thomson Catchment. Trade-offs in economic value associated with different forest uses were not examined in this study. Other approaches are needed to do this, such as integrated economic and environmental accounting (e.g. under the System of Environmental and Economic Accounting [SEEA]; (United Nations, 2012)). Studies using this methodology have been completed for the montane ash forests of the Central Highlands of Victoria (which includes the forest in the Thomson Catchment) (Keith et al., 2017). These studies show that the economic value of the water for Melbourne is 25.5 times greater than the economic value of the timber and pulp produced from logging in native forests. Therefore, on economic grounds, ongoing 
logging of the Thomson Catchment does not appear to maximize the public good derived from forest catchments.

A primary driver for logging in the Thomson Catchment is its inclusion in the current the Forests (Wood Pulp Agreement) Act 1996 (Parliament of Victoria, 1996), which forms the Legislative Supply Agreement binding the Victorian Government to supply a minimum of $350,000 \mathrm{~m}^{3}$ of pulplogs from state forests per annum to Paper Australia Pty Ltd. until 2030 (MBAC Consulting, 2006). Pulplogs are delivered to the Maryvale Pulp Mills, which are operated by Paper Australia Pty Ltd. A transition from state forests to plantations was proposed in 2006 by the previous owners of the Maryvale Mills (PaperlinX Ltd), where it committed to using $100 \%$ plantation-sourced fibre for its printing and communication papers by 2017 (PaperlinX Ltd, 2006). This commitment was later abandoned by the current owners of the Maryvale Mills who argued for continued access to state forests, including the Thomson Catchment (Poyry, 2011). However, the plantation estate across Victoria has rapidly expanded levels of wood production, and in 2017 provided domestic and export markets with 3.9 million tonnes of hardwood pulp logs (ABARES, 2017). Industry consultants (Poyry, 2011) have advised that it is technically feasible for Paper Australia Pty Ltd. to source all of its hardwood pulplog volumes from hardwood plantations.

The case of logging in the Thomson Catchment needs to be costed against the increasing demand for water, particularly when rainfall has been decreasing (Melbourne Water, 2018). Uncertainty becomes a challenge for future management of the catchment, particularly in the context of representative climate futures. Historical and continued logging risk negating, compounding and/or amplifying, water loss across the Thomson Catchment under climate change. Therefore, a possible set of policy options is to remove logging from the Thomson Catchment and replace wood products sourced from native forests with wood products then sourced from well managed plantations. This would significantly increase water supply to the reservoir. Due to plantations being more intensively managed, the employment lost from the native forest sector would be more than compensated for by employment in the plantation growing and processing sector.

\section{Conclusions}

Water security inmajor urban areas is of increasing concern globally. The maintenance of the integrity of forest cover in water catchments is critical to ensuring water security for urban settlements. We have modelled the effects on water yield of future forest management scenarios and the legacies of past forest management in the largest water catchment for the city of Melbourne, Australia's second largest city, and compared these to projected climate change impacts under multiple representative climate futures. Our analysis highlighted the value of removing the negative impacts of logging on water yield. Our investigation highlights the complexity of potential conflicts associated with the use of natural resources such as timber and water, along with the impacts of climate change.

\section{Acknowledgements}

Claire Shepherd assisted in editorial and other aspects of production of this paper.

The authors acknowledge the GunaiKurnai and Wurundjeri peoples, upon whose respective lands this study was conducted and upon which their sovereignty was never ceded. We wish to acknowledge their Elders past, present and emerging.

\section{Funding sources}

This research did not receive any specific grant from funding agencies in the public, commercial, or not-for-profitsectors.

\section{References}

ABARES, 2017. Australia's forests at a glance. http://www.agriculture.gov.au/abares forestsaustralia/australian-forest-and-wood-products-statistics, Accessed date: 16 October 2018.

ABS, 2018. 3218.0 - Regional Population Growth, Australia, 2016-17. http://www.abs.gov. au/ausstats/abs@.nsf/mf/3218.0, Accessed date: 16 October 2018.

Ashton, D., 1976. The development of even-aged stands of Eucalyptus regnans F. Muell. in central Victoria. Aust. J. Bot. 24, 397-414.

Benyon, R., Lane, P., Jaskierniak, D., Kuczera, G., Haydon, S., 2015. Use of a forest sapwood area index to explain long-term variability in mean annual evapotranspiration and streamflow in moist eucalypt forests. Water Resour. Res. 51, 5318-5331.

Bureau of Meteorology, 2018. Special climate statement 66-an abnormally dry period in eastern Australia. 1 November 2018. http://www.bom.gov.au/climate/current/statements/scs66.pdf, Accessed date: 3 February 2018.

Chalkley-Rhoden, S, 2017. Melbourne water supply could be under threat within a decade, water authority says. https://www.abc.net.au/news/2017-07-23/melbournewater-supply-could-be-under-threat-within-a-decade/8735400, Accessed date: 27 October 2018

Chiew,F.H.,McMahon, T.A., 2002. Modelling the impacts of climatechange on Australian streamflow. Hydrol. Process. 16, 1235-1245.

Chiew, F.H.S., Peel, M.C., Western, A.W., 2002. Application and testing of the simple rainfall-runoff model SIMHYD. In: Singh, V.P., Frevert, D.K. (Eds.), Mathematical Models of Small Watershed Hydrology and Applications. Water Resources Publication, Littleton, Colorado, USA.

Chiew, F.H.S., Teng,J., Vaze, J., Post, D.A., Perraud, J.M., Kirono, D.G.C., Viney, N.R., 2009. Estimating climate changeimpact on runoff across southeast Australia: method, results, and implications of the modeling method. Water Resour. Res. 45, W10414. https:// doi.org/10.1029/2008WR007338.

Clarke, J.M., Whetton, P.H., Hennessy, K., 2011. In: Chan, F., Marinova, D., Anderssen, R.S. (Eds.), Providing Application-Specific Climate Projections Datasets: CSIRO Climate Futures Framework. Modelling and Simulation Society of Australia and New Zealand, Perth, WA, pp. 2683-2690.

Clode, D., 2006. As if for a Thousand Years. Victorian Environment Assessment Council, Melbourne.

CSIRO and Bureau of Meteorology, 2015. Climate Change in Australia Information for Australia's Natural Resource Management Regions: Technical Report. https://www. climatechangeinaustralia.gov.au/media/ccia/2.1.6/cms_page media/168/CCIA_2015 NRM_TechnicalReport_WEB.pdf, Accessed date: 12 June 2019.

CSIRO and Bureau of Meteorology, 2016. State of the Climate 2016. http://www.bom.gov. au/state-of-the-climate/State-of-the-Climate-2016.pdf, Accessed date: 1 November 2016.

DELWP, 2007. Relative Age - SFRI. http:/ / services.land.vic.gov.au/SpatialDatamart/ dataSearchView Metadata.html?anzlicId $=$ ANZVI0803002820\&extractionProviderId=1, Accessed date: 12 June 2018.

DELWP, 2018a. Fire History. http:/ / services.land.vic.gov.au/SpatialDatamart/ dataSearchView Metadata.html?anzlicId $=$ ANZVI0803004741\&extractionProviderId=1, Accessed date: 12 June 2018.

DELWP, 2018b. LASTLOG25: logging history overlay of most recent harvesting activities. http://services.land.vic.gov.au/SpatialDatamart/dataSearchViewMetadata.html? anzlicId=ANZVI0803002521\&extractionProviderId=1, Accessed date: 12 June 2018.

DELWP, 2018c. NV2005_EVCBCS: Native Vegetation-Modelled 2005 Ecological Vegetation Classes (With Bioregional Conservation Status). At. http://services.land.vic.gov. au/SpatialDatamart/dataSearchViewMetadata.html?anzlicId = ANZVI0803003495\&extractionProviderId=1, Accessed date: 5 October 2018.

Emergency Victoria, 2019. Incidents and Warnings. https://www.emergency.vic.gov.au/ respond/, Accessed date: 8 March 2019.

Feikema, P., Lane, P., Sherwin, C.B., 2008. Hydrological Studies Into the Impact of Timber Harvesting on Water Yield in State Forests Supplying Water to Melbourne - Part 2 of Hydrological Studies (Climate Change and Bushfire). School of Forest and Ecosystem Science The University of Melbourne, Parkville.

Feikema, P.M., Sherwin, C.B., Lane, P.N.J., 2013. Influence of climate, fire severity and forest mortality on predictions of long term streamflow: potential effect of the 2009 wildfire on Melbourne's water supply catchments. J. Hydrol. 488, 1-16.

Flato, G., Marotzke, J., Abiodun, B., Braconnot, P., Chou, S.C., Collins, W., Cox, P., Driouech, F., Emori, S., Eyring, V., Forest, C., Gleckler, P., Guilyardi, E., Jakob, C., Kattsov, V., Reason, C., Rummukainen, M. 2013. Evaluation of climate models. In: Stocker, T.F., Qin, D., Plattner, G.-K., Tignor, M., Allen, S.K., Boschung, J., Nauels, A., Xia, Y., Bex, V., Midgley, P.M. (Eds) Climate Change 2013: The Physical Science Basis. Contribution of Working Group I to the Fifth Assessment Report of the Intergovernmental Panel on Climate Change. Cambridge University Press, Cambridge, United Kingdom and New York, NY, USA.

Flint, A., Fagg, P., 2007. Mountain Ash in Victoria's State Forests. Silviculture Reference Manual No. 1. Department of Sustainability and Environment, Melbourne.

Foley, J.A., Ramankutty, N., Brauman, K.A., Cassidy, E.S., Gerber, J.S., Johnston, M., Mueller, N.D., O'Connell, C., Ray, D.K., West, P.C., Balzer, C., Bennett, E.M., Carpenter, S.R., Hill, J., Monfreda, C., Polasky, S., Rockström, J., Sheehan, J., Siebert, S., Tilman, D., Zaks, D.P.M., 2011. Solutions for a cultivated planet. Nature 478, 337.

Frost, A.J., Ramchurn, A., Smith, A., 2018. The Australian Landscape Water Balance Model (AWRA-L v6). Technical Description of the Australian Water Resources Assessment Landscape Model Version 6. Bureau of Meteorology, Canberra.

Gerbing, C., Webb, L., Grose, M., 2015. SouthernSlopes Cluster Report. CSIROand Bureau of Meteorology, Melbourne.

Hamilton, L.S., 2008. Forests and Water: A Thematic Study Prepared in the Framework of the Global Forest Resources Assessment 2005. Food and Agriculture Organisation of the United Nations, Rome. 
Hollis, G., 2004. Ecology and Conservation Biology of the Baw Baw Frog Philoria frosti (Anura: Myobatrachidae): Distribution, Abundance, Autoecology and Demography. $\mathrm{PhD}$ Thesis thesis. University of Melbourne.

Hope, P., Abbs, D., Bhend, J., Chiew, F., Church, J., Ekström, M., Kirono, D., Lenton, A., Lucas, C., McInnes, K., Moise, A., Monselesan, D., Mpelasoka, F., Timbal, B., Webb, L., 2015. Southern and south-western flatlands cluster report. In: Ekström, M., Whetton, P. Gerbing, C., Grose, M., Webb, L., Risbey, J. (Eds.), Climate Change in Australia Projections for Australia's Natural Resource Management Regions. CSIRO and Bureau of Meteorology, Melbourne.

Howe, C., Jones, R.N., Maheepala, S., Rhodes, B., 2005. Implications of Potential Climate Change for Melbourne's Water Resources. CSIRO, Victorian Government, Melbourne Water, Melbourne.

Jaskierniak, D., 2011. Modelling the Effects of Forest Regeneration on Streamflow Using Forest Growth Models. PhD Thesis. University of Tasmania.

Jaskierniak, D., Kuczera, G., Benyon, R., 2016. Predicting long-term streamflow variability in moist eucalypt forests using forest growth models and a sapwood area index. Water Resour. Res. 52, 3052-3067.

Keating, B.A., Carberry, P.S., Hammer, G.L., Probert, M.E., Robertson, M.J., Holzworth D., Huth, N.I., Hargreaves, J.N.G., Meinke, H., Hochman, Z., McLean, G., Verburg, K., Snow, V., Dimes, J.P., Silburn, M., Wang, E., Brown, S., Bristow, K.L., Asseng, S., Chapman, S., McCown, R.L., Freebairn, D.M., Smith, C.J., 2003. An overview of APSIM, a model designed for farming systems simulation. Eur. J. Agron. 18, 267288.

Keith, H., Vardon, M., Stein, J.A., Stein, J.L., Lindenmayer, D.B., 2017. Ecosystem accounts define explicit and spatial trade-offs for managing natural resources. Nature Ecol. Evol. 1, 1683-1692.

Kokic, P., Breckling, J., Lübke, O., 2002. A new definition of multivariate M-quantiles. In Dodge, Y. (Ed.), Statistical Data Analysis Based on the L1-Norm and Related Methods. Birkhäuser Verlag, Basel.

Kuczera, G., 1987. Prediction of water yield reductions following a bushfire in ash-mixed species eucalypt forest. J. Hydrol. 94, 215-236.

Lane, P.N.J., Feikema, P.M., Sherwin, C.B., Peel, M.C., Freebairn, A.C., 2010. Modelling the long term water yield impact of wildfire and other forest disturbance in Eucalypt forests. Environ. Model. Softw. 25, 467-478.

Langford, K., O'Shaughnessy, P., 1980. A Case Study of Maroondah Catchment. Melbourne and Metropolitan Board of Works, Melbourne.

Lindenmayer, D.B., McCarthy, M., 1998. Multi-aged mountain ash forest, wildlife conservation and timber harvesting. For. Ecol. Manag. 104, 43-56.

Lindenmayer, D.B., Mackey, B.G., Nix, H.A., 1996. The bioclimatic domains of four species of commercially important eucalypts from south-eastern Australia. Aust. Forestry 59, $74-89$.

Lindenmayer, D.B., Hobbs, R.J., Likens, G.E., Krebs, C., Banks, S., 2011. Newly discovered landscape traps produce regime shifts in wet forests. Proc. Natl. Acad. Sci. U. S. A. $108,15887-15891$.

Lindenmayer, D.B., Blanchard, W., McBurnie, L., Blair, D., Banks, S.C., Driscoll, D., Smith A.L., Gill, A.M., 2013. Fire severity and landscape context effects on arboreal marsupials. Biol. Conserv. 167, 137-148.

Lindenmayer, D.B., Blair, D.P., McBurney, L., Banks, S.C., 2015. Mountain Ash: Fire, Logging and the Future of Victoria's Giant Forests. CSIRO Publishing, Melbourne.

Luo, P., Zhou, M., Deng, H., Lyu, J., Cao, W., Takara, K., Nover, D., Schladow, S.G., 2018. Impact of forest maintenance on water shortages: hydrologic modeling and effects of climate change. Sci. Total Environ. 615, 1355-1363.

Lutze, M.T., Campbell, R.G., Fagg, P.C., 1999. Development of silviculture in the native forests of Victoria. Aust. Forestry 62, 236-244

Mackey, B., Lindenmayer, D.B., Gill, M., McCarthy, M., Lindesay, J., 2002. Wildlife, Fire and Future Climate: A Forest Ecosystem Analysis. CSIRO Publishing, Collingwood.

Mansergh, I.M., Norris, K.C., 1982. Sites of Zoological Significance in Central Gippsland Volume I. Ministry for Conservation, Victoria.

MBAC Consulting, 2006. Feasibility of Plantations Substituting for Timber Currently Harvested From Melbourne's Water Catchments. MBAC Consulting, Tugan.

Mein, R., 2008. Potential Impacts of Forest Management on Streamflow in Melbourne's Water Supply Catchments: Summary Report. R G Mein \& Associates.

Melbourne Water, 2016. Enhancing Life and Liveability: Annual Report 2015-16. Melbourne Water, Melbourne.

Melbourne Water, 2017. Thomson Reservoir. https://www.melbournewater.com.au/ community-and-education/about-our-water/water-storage-reservoirs/Thomson, Accessed date: 25 August 2018.

Melbourne Water, 2018. Melbourne Water Annual Report 2017-18. Melbourne Water, Melbourne.

Melbourne Water, 2019. Water Storage and Use. https://www.melbournewater.com.au/ water/water-storage-and-use\#/, Accessed date: 7 March 2019.

Meyer, R.S., Cullen, B.R., Whetton, P.H., Robertson, F.A., Eckard, R.J., 2018. Potential impacts of climate change on soil organic carbon and productivity in pastures of south eastern Australia. Agric. Syst. 167, 34-46.

Mueck, S.G., 1990. The Floristic Composition of Mountain Ash and Alpine Ash Forests in Victoria: Silvicultural Systems Project No. 4. Department of Conservation and Environment, Melbourne,

Murphy, B.F., Timbal, B., 2008. A review of recent climate variability and climate change in southeastern Australia. Int. J. Climatol. 28, 859-879.

Nippon Paper Group Inc, 2009. Annual Report 2009. Nippon Paper Group Inc, Tokyo.

O'Leary, G.J., Christy, B., Nuttall, J., Huth, N., Cammarano, D., Stöckle, C., Basso, B., Shcherbak, I., Fitzgerald, G., Luo, Q., Farre-Codina, I., Palta, J., Asseng, A., 2015. Response of wheat growth, grain yield and water use to elevated $\mathrm{CO} 2$ under a free-air $\mathrm{CO} 2$ enrichment (FACE) experiment and modelling in a semi-arid environment. Glob. Chang. Biol. 21, 2670-2686.
O'Shaughnessy, P., Jayasuriya, J., 1991. Managing the ash-type forest for water production in Victoria. In: McKinnell, F.H., Hopkins, E.R., Fox, J.E.D. (Eds.), Forest Management in Australia. Surrey Beatty and Sons, Chipping Norton.

PaperlinX Ltd, 2006. Concise Annual Report 2006. PaperlinX Ltd, Mt Waverly. Parliament of Victoria, 1936. Wood Pulp Agreement 1936. Parliament of Victoria Melbourne.

Parliament of Victoria, 1996. Forest (Wood Pulp Agreement) Act 1996. Parliament of Victoria, Melbourne.

Peel, M., Watson, F., Vertessy, R., Lau, A., Watson, I., Sutton, M., Rhodes, B. 2000. 'Predicting the Water Yield Impacts of Forest Disturbance in the Maroondah and Thomson Catchments Using the Macaque Model.' CRC for Catchment Hydrology, Melbourne Water and DNRE, Melbourne.

Penman, H.L., 1948. Natural evaporation from open water, bare soil and grass. Proc. R. Soc A 193, 120-145. https://doi.org/10.1098/rspa.1948.0037.

Perraud, J.M., Podger, G.M., Rahman, J.M., Vertessy, R.A., 2003. A new rainfall runoff software library. Proc. MODSIM 4, 1733-1738.

Poyry, 2011. VicForests and Australian Paper: Review of Issues Affecting the Transition of Victoria's Hardwood Processing Industry from Native Forests to Plantations. Poyry Management Consulting (Australia) Pty Ltd, Melbourne.

Prober, S.M., Colloff, M.J., Abel, N., Crimp, S., Doherty, M.D., Dunlop, M., Eldridge, D.J., Gorddard, R., Lavorel, S., Metcalfe, D.J., Murphy, H.T., 2017. Informing climate adaptation pathways in multi-use woodland landscapes using the values-rules-knowledge framework. Agric. Ecosyst. Environ. 241, 39-53.

Randall, D.A., Wood, R.A., Bony, S., Colman, R., Fichefet, T., Fyfe, J., Kattsov, V., Pitman, A., Shukla, J., Srinivasan, J., Stouffer, R.J., Sumi, A., Taylor, K.E., 2007. Climate models and their evaluation. In: Oin Solomon, S.D., Manning, M., Chen, Z., Marquis, M. Averyt, K.B., Tignor, M., Miller, H.L. (Eds.), Climate Change 2007: The Physical Science Basis. Contribution of Working Group I to the Fourth Assessment Report of the Intergovernmental Panel on Climate Change. Cambridge University Press, Cambridge, United Kingdom and New York, NY, USA.

Read Sturgess and Associates, 1994. Phase Two of theStudy into the Economic Evaluation of Wood and Water for the Thomson Catchment. Melbourne Water and Department of Conservation and Natural Resources, Melbourne.

Revi, A., Satterthwaite, D.E., Aragón-Durand, F., Corfee-Morlot, J., Kiunsi, R.B.R., Pelling, M., Roberts, D.C., Solecki, W., 2014. Urban areas. In: Field, C.B., Barros, V.R., Dokken, D.J., Mach, K.J., Mastrandrea, M.D., Bilir, T.E., Chatterjee, M., Ebi, K.L., Estrada, Y.O., Genova, R.C., Girma, B. Kissel, ES, Levy, A.N., MacCracken, S., Mastrandrea, P.R, White, L.L. (Eds.), Climate Change 2014: Impacts, Adaptation, and Vulnerability. Part A: Global and Sectoral Aspects. Contribution of Working Group II to the Fifth Assessment Report of the Intergovernmental Panel on Climate Change. Cambridge University Press, Cambridge, United Kingdom and New York, NY, USA.

Riahi, K., Rao, S., Krey, V., Cho, C., Chirkov, V., Fischer, G., Kindermann, G., Nakicenovic, N., Rafaj, P., 2011. RCP 8.5-a scenario of comparatively high greenhouse gas emissions. Clim. Chang. 109, 33. https://doi.org/10.1007/s10584-10011-10149-y.

Ronan, N., Duncan, H., 1980. Production of timber and water. In: Langford, K.J., O'Shaughnessy, P.J. (Eds.), A Case Study of Maroondah Catchment. Melbourne and Metropolitan Board of Works, Melbourne.

Ruane, A.C., McDermid, S.P., 2017. Selection of a representative subset of global climate models that captures the profile of regional changes for integrated climate impacts assessment. Earth Perspectives 4, 1. https:/ / doi.org/10.1186/s40322- 0170036-4.

Schyns, J., Booij, M., Hoekstra, A., 2017. The water footprint of wood for lumber, pulp, paper, fuel and firewood. Adv. Water Resour. 107, 490-501.

Smith, A.L., Blair, D., McBurney, L., Banks, S., Barton, P.S., Blanchard, W., Driscoll, D., Gill, A.M., Lindenmayer, D.B, 2014. Dominant drivers of seedling establishment in a firedependent obligate seeder: climate or fire regimes? Ecosyst 17, 258-270.

Stokes, C., Howden, M., 2010. Adapting Agriculture to Climate Change: Preparing Australian Agriculture, Forestry and Fisheries for the Future. CSIRO Publishing, Collingwood.

Taylor, C., McCarthy, M.A., Lindenmayer, D.B., 2014. Nonlinear effects of stand age on fire severity. Conserv. Lett. 7, 355-370.

Taylor, C., Cullen, B., D'Occhio, M., Rickards, L., Eckard, R., 2018. Trends in wheat yields under representative climate futures: implications for climate adaptation. Agric. Syst. 164, 1-10.

Thompson, L.H.S., 1961. Forests (Wood Pulp Agreement) Bill. Melbourne Turnbull, J.W., Pryor, D.L., 1984. Choice of species and seed sources. In: Hillis, W.E., Brown, A.G. (Eds.), Eucalypts for Wood Production. CSIRO Publishing and Academic Press, Collingwood.

UNDESA (United Nations Department of Economic and Social Affairs), 2016. The World's Cities 2016. Statistical Papers - United Nations (Ser. A), Population and Vital Statistics Report. United Nations, New York https://doi.org/10.18356/8519891f-en Available at.

United Nations, 2012. System of Environmental-Economic Accounting Central Framework. United Nations, New York.

Van Vuuren, D.P., Edmonds, J., Kainuma, M., Riahi, K., Thomson, A., Hibbard, K., Hurtt, G.C., Kram, T., Krey, V., Lamarque, J.F., Masui, T., 2011. The representative concentration pathways: an overview. Clim. Chang. 109, 5. https://doi.org/10.1007/s10584-1001110148-z.

Vertessy, R.A., Watson, F., O'Sullivan, S., Davis, S., Campbell, R., Benyon, R., Haydon, S., 1998. Predicting Water Yield From Mountain Ash Forest Catchments. CRC for Catchment Hydrology, Clayton, Victoria.

Vertessy, R.A., Watson, F.G.R., O'Sullivan, S.K., 2001. Factors determining relations between stand age and catchment water balance in mountain ash forests. For. Ecol. Manag. 143, 13-26.

VicForests, 2019. Timber Release Plan (Including Approved Changes), April 2019. http:// www.vicforests.com.au/planning-1/timber-release-plan-1/approved-timber-releaseplan-april-2019, Accessed date: 12 June 2019. 
Viggers, J., Weaver, H., Lindenmayer, D.B., 2013. Melbourne's Water Catchments: Perspectives on a World-Class Water Supply. CSIRO Publishing, Melbourne.

Walsh, N., Entwisle, T., 1996. Flora of Victoria. Dicotyledons: Winteraceae to Myrtaceae. vol.3. Inkata Press, Melbourne.

Watson, F.G.R., Vertessy, R.A., McMahon, T.A., Rhodes, B.G., Watson, I.S., 1998. The Hydrologic Impacts of Forestry on the Maroondah Catchments. Cooperative Research Centre for Catchment Hydrology, Melbourne.
Whetton, P.,Hennessy, K., Clarke, J., McInnes, K., Kent, D., 2012. Use of Representative Climate Futures in impact and adaptation assessment. Clim. Chang. 115, 433-442.

WWAP(United Nations World Water AssessmentProgramme), 2015. The United Nations World Water Development Report 2015: Water for a Sustainable World. UNESCO, Paris.

Zylstra, P., 2018. Flammability dynamics in the Australian Alps. Austral Ecol. 43, 578-591. 